\title{
In situ observations of the association between juvenile fishes and scyphomedusae in the Bering Sea
}

\author{
Richard D. Brodeur* \\ National Marine Fisheries Service, Alaska Fisheries Science Center, 7600 Sand Point Way NE, Seattle, \\ Washington 98115, USA
}

\begin{abstract}
In September 1995, dense aggregations of large scyphomedusae (mainly Chrysaora melanaster) were observed in 27 midwater deployments of a remotely operated vehicle (ROV) near the Pribilof Islands in the Bering Sea. Age-0 walleye pollock Theragra chalcogramma appeared to be frequently associated with these gelatinous zooplankton. During daytime, up to 30 pollock were observed swimming within the tentacles of these medusae, but when approached by the ROV, the pollock generally left the vicinity of the jellyfish. At night, few such associations were observed and juvenile pollock moved closer to the surface, apparently feeding in loose aggregations, while the medusae remained close to the thermocline $(35-40 \mathrm{~m})$. Prowfish Zaprora silenus were also observed near large medusae, but tended to be found closer to the bell rather than within the tentacles. The lack of any gelatinous material in the stomachs of the pollock suggests that juvenile pollock associate to gain shelter from predation or possibly as a thigmotactic response to biotic structure. The implications of this commensal behavior with gelatinous zooplankton are discussed relative to pollock recruitment in the Eastern Bering Sea.
\end{abstract}

KEY WORDS: Juvenile pollock - Theragra chalcogramma Scyphomedusae Commensalism - Underwater video

\section{INTRODUCTION}

Numerous studies have examined the association between the early life stages of marine fishes and the physical environment in which they live. Although physical conditions may often play an important role in the developmental rate, distribution, and dispersion of ichthyoplankton, it is apparent that, by the late larval and juvenile stages, biological factors (e.g. food availability and predator abundance and encounter rate) become increasingly important in influencing distribution and abundance. Although often overlooked, biotic structure in the pelagic environment may play an important role in the distribution and survival of juvenile fishes. Examples of biotic structures include large aggregates (e.g. marine snow), floating seaweeds and algae, and gelatinous zooplankton (Kingsford 1993).

•E-mail: rbrodeur@afsc.noaa.gov
Gelatinous zooplankton are recognized as important and occasionally obligate hosts for many invertebrates (Thiel 1976, Laval 1980). Associations with a wide diversity of fish taxa are also well known (Mansueti 1963, Thiel 1978, Arai 1988, 1997, Kingsford 1993). Associations of juvenile North Atlantic gadoid fishes with gelatinous zooplankton are well-documented due to the high abundance and considerable economic importance of gadoids in boreal waters (Dahl 1961, Mansueti 1963, Bailey 1975, Koeller et al. 1986, Hay et al. 1990).

Walleye pollock Theragra chalcogramma is the most abundant commercially exploited gadoid species in the North Pacific Ocean and Bering Sea and plays a critical role in these ecosystems (Springer 1992). Juvenile pollock are particularly important because they provide an important link through which energy flows between the lower trophic levels and apical predators (Springer 1992, Brodeur \& Wilson 1996a, Brodeur et al. 1996). The relationship between gelatinous zooplankton and juvenile pollock is poorly understood and most 
available information is anecdotal. Schools of late larval (17 to $24 \mathrm{~mm}$ ) pollock were found to be associated with the scyphomedusa Cyanea capillata in near-surface waters of Prince William Sound in the northern Gulf of Alaska by van Hyning \& Cooney (1974). These authors noted that the pollock were not found within the tentacles and speculated that the association may have been mainly due to an attraction to floating objects. Based on observations by scuba divers, Hamner (1983) reported that small age-0 pollock swam within the tentacles of medusae (Chrysaora sp.) in the Bering Sea, but no quantitative information was presented.

In this paper, I provide evidence, based on in situ underwater video observations, that age-0 walleye pollock are commonly associated with large scyphomedusae in the Bering Sea, document other fishes commensal with these medusae, examine diel occurrence and vertical distribution of these associations, and discuss the implications of this commensal behavior for the recruitment dynamics of juvenile pollock.

\section{METHODS}

Sampling methodology. During 11 to 25 September 1995, a Super Phantom 2 ROV (remotely operated vehicle; Deep Ocean Engineering, San Leandro, CA, USA) was deployed from the NOAA RV 'Miller Freeman' at locations around the Pribilof Islands in the Eastern Bering Sea (Fig. 1). A downweight (108 kg) was attached to the $320 \mathrm{~m}$ umbilical cord to provide stability and to prevent the ROV from trailing while the vessel drifted. The ROV was attached to an additional $25 \mathrm{~m}$ of umbilical beyond the downweight which allowed free movement in all directions. The ROV contained an Osprey OE1323 Silicon Intensifier Target low-light video camera and a Hitachi HV-C20 CCD color camera. Two $250 \mathrm{~W}$ tungsten-halogen lights provided illumination. An on-deck console with camera, light, and thruster controls and real-time depth readout and video monitor provided the operator with the ability to maneuver the ROV along transects or track individual objects.

A total of 27 (14 day and 13 night) deployments were done at 24 locations (depth range 35 to $214 \mathrm{~m}$ ) along specified transects or in areas which showed strong acoustic signals such as at oceanographic fronts. The main purpose of the study was to observe age-0 walleye pollock in midwater (Brodeur et al. 1997). A Simrad EK-500 echo integrator interfaced to 38 and $120 \mathrm{kHz}$ split-beam transducers was used to locate acoustic sign likely to be age- 0 fish based on target strength information (Brodeur \& Wilson 1996b). Water column structure (Conductivity/Temperature/Depth) was measured at most stations with a Seabird Model SBE-9 CTD system (Brodeur et al. 1997). Net sampling was conducted at all stations with a $100 \mathrm{~m}^{2}$ anchovy trawl containing a $3 \mathrm{~mm}$ mesh liner (Brodeur et al. 1995), which was towed through the depth range examined with the ROV to determine taxonomic and size composition of the animals observed. This gear effectively samples the full range of juvenile fish sizes likely to be present at this time of year (Brodeur unpubl. data).

The trawl catches were sorted to species on deck and length measurements were made on juvenile pollock and other fishes to the nearest millimeter. Umbrella diameters were measured to the nearest $5 \mathrm{~mm}$ on a subsample of large scyphozoan and hydrozoan medusae. In addition, total weights were taken for each taxon caught in the trawls. Catches were converted to densities per $1000 \mathrm{~m}^{3}$ based on estimates of volume filtered for each trawl (Wilson et al. 1996).

Data analysis. The videos were recorded on NTSC standard Hi-8 format tapes and were time coded (date, hour, minute, second) to facilitate multiple viewing and comparison with real-time field notes on depth and environmental conditions. The tapes were reviewed by a trained observer who tabulated data on species composition of medusae and fish seen in the videos. This observer was unaware of the diel period or location of
Fig. 1. Locations (O) of 27 ROV (remotely operated vehicle) deployments around the Priblilof Islands, Bering Sea, during September 1995 
Fig. 2. Theragra chalcogramma and Chrysaora melanaster. Juvenile pollock swimming among the tentacles of $C$. melanaster in the Bering Sea during a daytime? (19:50 h Alaska Daylight Time,

ADT) ROV deployment ( $38 \mathrm{~m}$ depth)

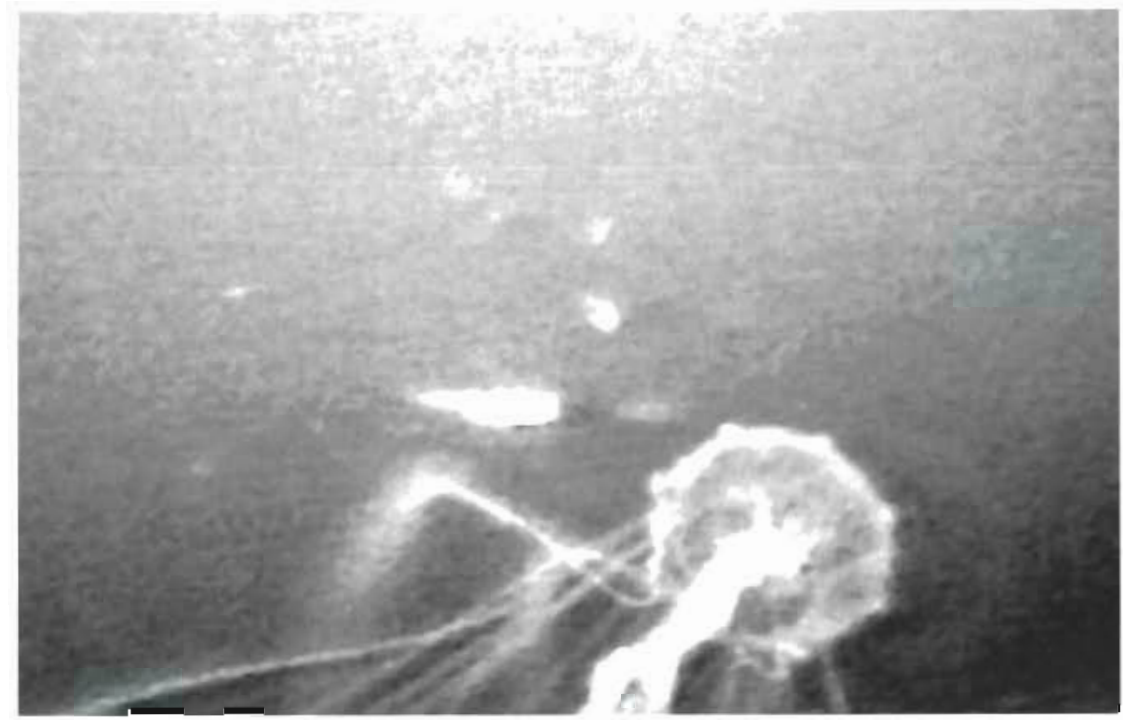

the deployment in order to minimize observational bias. Only medusae that were entirely and clearly visible in the frame were included in the analysis, but the individuals which were only partially observed (umbrella or tentacles only) were also logged.

Due to uncertainties in the volume of water observed by the ROV at different times of day and in waters of varying clarity, density estimates were not derived for the medusae or pollock from these observations. However, during some deployments, the entire water column was sampled equally without stopping at any one depth and these segments of the videotapes were analyzed for vertical distribution of pollock and medusae. Data were summarized as to the number of occurrences of medusae observed both with and without juvenile fishes, the number of fish per individual medusae, and the number of occurrences of fish without any medusae observed nearby. The location of the fish with respect to the body of the medusae was also noted for all associations.

\section{RESULTS}

\section{ROV observations}

Scyphomedusae (Chrysara melanaster and Cyanea capillata) were the most visible macrofauna observed in the water column and were seen during 26 of the 27 deployments. A total of 3196 C. melanaster were observed in video footage, of which 580 were clearly and completely visible for analysis of fish associations. Although it was not possible to get quantitative estimates of their abundance or size from the videos, at least 1 large $C$. melanaster was within view at all times in the densest aggregation layers $(20-40 \mathrm{~m})$ In most cases, the medusae pulsated in an upright fashion with the long tentacles (estimated to be $>10 \mathrm{~m}$ in some cases) streaming down (Fig 2). C. capillata, with many densely packed but shorter $(<2 \mathrm{~m})$ tentacles, swam in a similar fashion but were far less common $(n=18)$ than C. melanaster. Other scyphomedusae (Aurelia sp.), hydromedusae (mainly Aequorea sp.), and ctenophores (Beroe sp.) were also infrequently observed in the video footage.

Age-0 walleye pollock were often seen swimming among the tentacles of Chrysaora melanaster, especially during daytime deployments (Fig. 2). A total of 203 separate co-occurrences of pollock with $C$. melanaster and 5 with $C$. capillata were observed during the 27 dives. The pollock were generally found well down the length of the tentacles away from the umbrella of the jellyfish. Up to 30 pollock were observed in association with one medusa, with an overall mean of 3.0 pollock per medusa. When approached by the ROV, the pollock would move away from the medusae. The majority of $C$. melanaster and associated pollock were observed over a narrow $(30-40 \mathrm{~m}$ ) depth range during the day (Fig. 3).

At night, a different behavior was observed in that pollock apparently left the medusae, ascended closer to the surface $(5$ to $30 \mathrm{~m}, \mathrm{Fig} .3$ ), and were found in large, dense aggregations (Fig 4). The random orientation of the fish and their continuous jaw movements as observed with the ROV suggested that these fish were probably feeding at this time. These juveniles did not appear to be affected by the motion of the ROV or by the camera lights. Scyphomedusae were also frequently observed during these night dives, but they were found at greater depths (25 to $45 \mathrm{~m}$, Fig. 3) than the pollock and generally did not have juvenile pollock associated with them. 

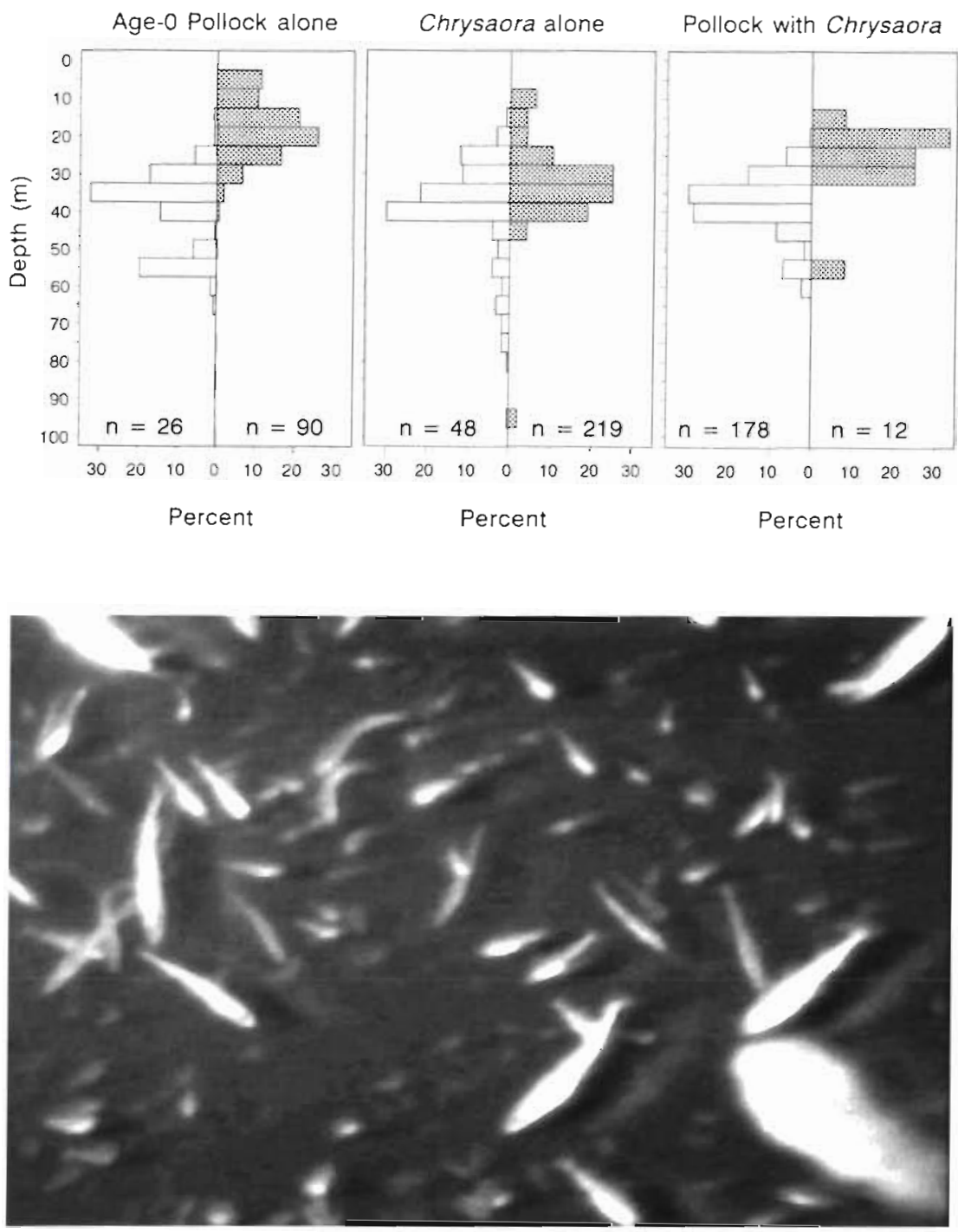

Fig. 3. Theragra chalcogramma and Chrysaora melanaster. Day (open bars) and night (filled bars) vertical distrubution of age- 0 pollock and $C$. melanaster both alone and in association with one another based on ROV observations. Data are the percent frequency by $5 \mathrm{~m}$ depth intervals of the occurrences of age-0 pollock and C. melanaster observed alone and the occurrence of the associations. Observations are summed from 13 daytime and 7 nighttime deployments for which sufficient depth information existed. Number of occurrences are listed at the bottom of each panel
The association between juvenile pollock and Chrysara melanaster showed a marked diel pattern (Fig. 5). Both the mean number of pollock per medusa and the percentage of total quantifiable medusae which were associated with at least 1 juvenile pollock were substantially higher during daylight hours. Both these indices were at or near zero during the night (Fig. 5). Age-0 pollock and C. melanaster were found to associate at a significantly higher rate during the day and tended not to be found together at night ( $G$-test of Association $=176.5$ and 292.4 for pollock and $C$. melanaster, respectively; both $p<0.0001)$. The mean and median depths of age- 0 pollock and $C$. melanaster alone and those of their co-occurrence also varied significantly between day and night (Table 1, Fig. 3).

Juvenile prowfish Zaprora silenus were observed in association mainly with large Cyanea capillata $(n=31)$ but also were found with some larger Chrysaora melanaster ( $\mathrm{n}=5$ ). They were most often seen swimming around the top and sides of the bell, but, when approached by the ROV, they retreated behind the tentacles or within the bell of the jellyfish. Up to 9 juvenile $Z$. silenus were observed around a single C. capillata. None of these fish were seen swimming in open areas any distance away from medusae. One other fish species, which has tentatively been identified as crested sculpin Blepsias bilobus, was observed on 1 occasion swimming around the bell of a medusa.

\section{Acoustic patterns and trawl catches}

The acoustic patterns observed varied substantially by location and time. A typical daytime (18:20 h Alaska Daylight Time, ADT) pattern seen offshore of the front north of St. Paul Island was a heavy concentration of 
Fig. 5. Theragra chalcogramma and Chrysaora melanaster. Association of juvenile pollock with $C$. melanaster showing mean number of pollock per medusa when they co-occurred and percentage of total quantifiable medusae that were associated with walleye pollock by time of day. Time of sunrise (SR) and sunset (SS) shown at top of graph

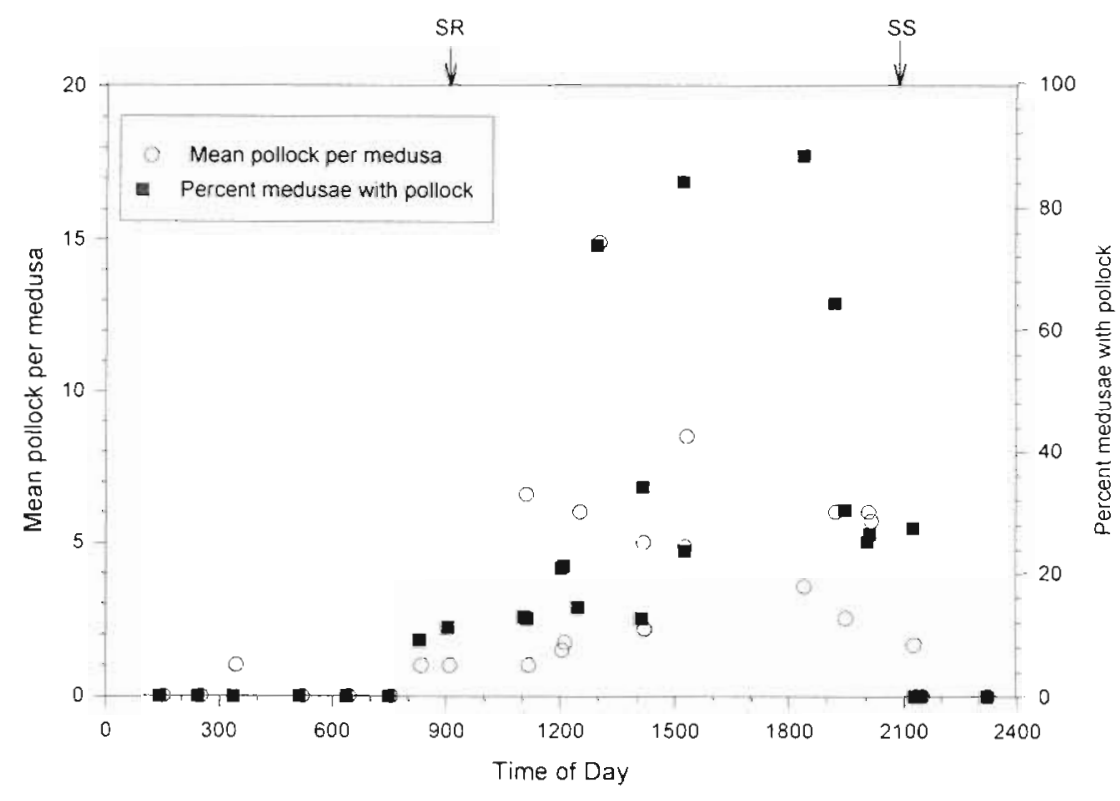

0.57, $\mathrm{n}=16$ ) was found for night hauls (Fig. 7). Since these anchovy trawls were targeting acoustic sign suspected to be age-0 pollock, this lack of a relationship suggests that the pollock and medusae are found in different layers at night.

Overall, the mean catch per haul of age-0 pollock was slightly higher during the day trawls (23.9 fish $\left.1000 \mathrm{~m}^{-3}\right)$ than at night $\left(19.8\right.$ fish $\left.1000 \mathrm{~m}^{-3}\right)$, but this difference was not significant. The size distributions of age-0 pollock collected in the anchovy trawls were similar during both day and night (Fig, 8) and the mean lengths were virtually identical $(54.76 \mathrm{~mm}$ and depths ( -47 to $-55 \mathrm{~dB}$ ) and an empirically-derived tar get strength/fish length relationship (Bradeur \& Wilson 1996b), these scatterers were most likely age-0 pollock.

The catch composition of the anchovy trawls was dominated by age-0 pollock among the fishes and by Chrysaora melanaster among the invertebrates (Table 2). Both these species occurred in all 34 trawls made and constituted the vast majority of the numerical composition of their respective categories. The next most frequently occurring species in each category (Zaprora silenus and Cyanea capillata) both had relatively low densities compared to the dominants (Table 2). The catches of age-0 pollock showed a significant positive relationship (geometric mean regression: $F=$ 7.57, $\mathrm{p}=0.014, \mathrm{n}=18$ ) to the total catch of cnidarians in each trawl for daytime hauls, but no relationship $(F=0.33, p=$
Table 1. Theragra chalcogramma and Chrysaora melanaster. Diel differences in the mean and median depths of age-0 walleye pollock alone, C. melanaster alone, and the association of both species. Also given are the results of a $t$-test and nonparametric Mann-Whitney $U$-test for differences in mean and median depths, respectively, by time of day. Sample sizes are given in Fig. $3 .{ }^{\prime} p \leq 0.01$, $\cdots p \leq 0.001$

\begin{tabular}{|c|c|c|c|c|c|}
\hline & Time & $\begin{array}{c}\text { Mean } \\
\text { depth }(m)\end{array}$ & t-value & $\begin{array}{l}\text { Median } \\
\text { depth (m) }\end{array}$ & $U$-value \\
\hline \multirow[t]{2}{*}{ Age-0 pollock } & Day & 39.3 & \multirow[b]{2}{*}{$12.3 \cdots$} & 36 & \multirow[b]{2}{*}{$718.5^{\cdots}$} \\
\hline & Night & 19.8 & & 19 & \\
\hline \multirow[t]{2}{*}{ C. melanaster } & Day & 39.7 & \multirow[b]{2}{*}{$3.9 \cdots$} & 38 & \multirow[b]{2}{*}{$329.1 \cdots$} \\
\hline & Night & 32.1 & & 33 & \\
\hline \multirow[t]{2}{*}{ Association } & Day & 37.6 & \multirow{2}{*}{$7.7^{\cdots}$} & 37 & \multirow{2}{*}{$1079.5 \cdots$} \\
\hline & Night & 26.3 & & 25 & \\
\hline
\end{tabular}




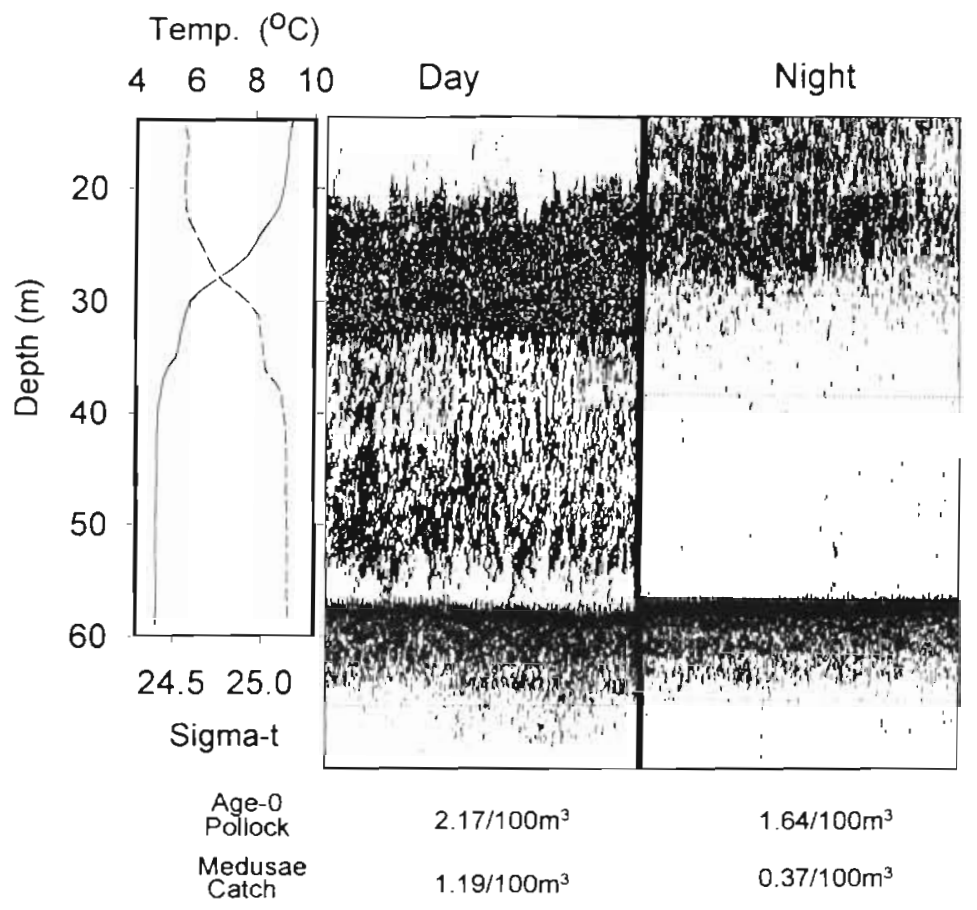

Fig. 6. Day (18:20 h ADT) and night $(22: 30 \mathrm{~h}$ $A D T$ ) differences in vertical distribution and aggregation patterns of sound scatterers at the same location $\left(57.22^{\circ} \mathrm{N}, 170.1^{\circ} \mathrm{W}\right)$ at the frontal region north of St. Paul Island. Also shown are the temperature and density (sigma-t) profiles and the catch of age-0 walleye pollock and gelatinous zooplankton in each period corresponding to this location

$54.77 \mathrm{~mm}$, respectively), implying the same population was sampled at both times. The total gelatinous zooplankton mean density in the trawls was significantly ( $p=0.003$ ) lower during the night $\left(4.9\right.$ ind. $1000 \mathrm{~m}^{-3}$ ) than during the day $\left(16.7\right.$ ind. $\left.1000 \mathrm{~m}^{-3}\right)$. The tows were made through the high density sign observed by the

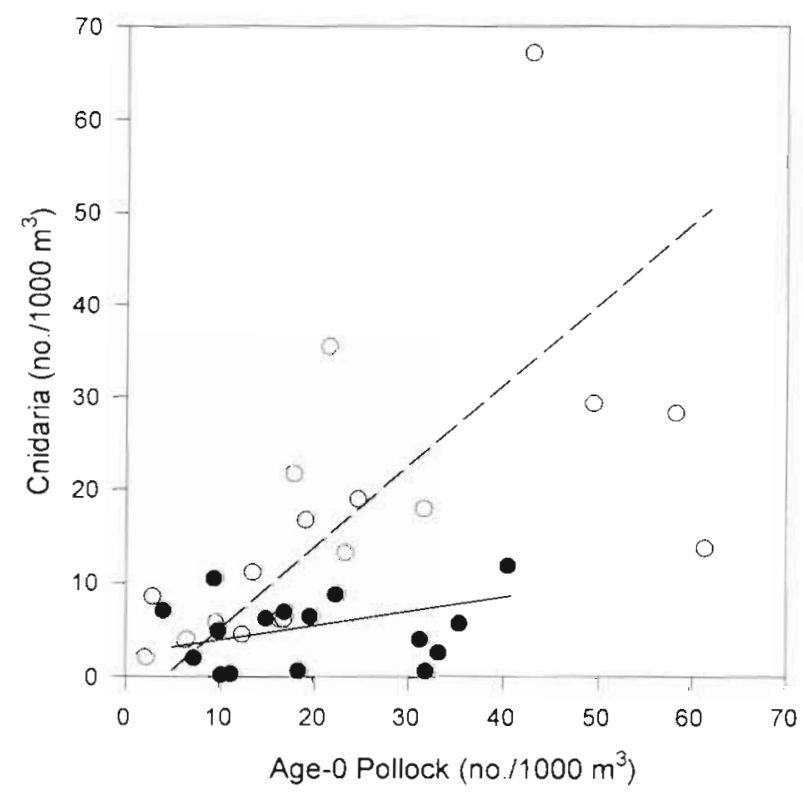

Fig. 7. Relation between the abundance of juvenile pollock and large gelatinous zooplankton caught in anchovy trawls at 32 stations around the Pribilof Islands. (O) Daytime hauls; (-) nighttime hauls. Dashed and solid lines are the geometric mean regression fits to each data set
$38 \mathrm{kHz}$ echosounder, which corresponds mainly to pollock concentrations; this suggests that the jellyfish were not found in the same layer as the age-0 juveniles at night. The catches of the dominant scyphomedusan species (Chrysaora melanaster) consisted of a broad range of umbrella diameters, but the majority were less than $20 \mathrm{~cm}$ (Fig. 9). Among the less abundant gelatinous species, Cynaea capillata also occurred over a wide range of sizes, but Aequorea forskalea and Aurelia aurita were mostly restricted to $<20 \mathrm{~cm}$ umbrella diameters.

Table 2. Summary of the 5 most abundant fish and invertebrate species caught in the anchovy trawl arranged in order of decreasing percent frequency of occurrence ( $\%$ FO)

\begin{tabular}{|c|c|c|c|c|}
\hline \multirow[t]{2}{*}{ Taxon } & \multirow[t]{2}{*}{$\begin{array}{c}\% F O \\
(n=34)\end{array}$} & \multicolumn{2}{|c|}{$\begin{array}{c}\text { Density } \\
\left.\text { (no. } 1000 \mathrm{~m}^{-3}\right)\end{array}$} & \multirow[t]{2}{*}{$\begin{array}{l}\% \text { of } \\
\text { total }\end{array}$} \\
\hline & & Mean & $\mathrm{SE}$ & \\
\hline \multicolumn{5}{|l|}{ Fish } \\
\hline Theragra chalcogramma & 100.0 & 22.05 & 2.61 & 99.71 \\
\hline Zaprora silenus & 32.3 & 0.01 & 0.01 & 0.05 \\
\hline Gadus macrocephalus & 26.5 & 0.01 & 0.01 & 0.05 \\
\hline Atheresthes stomias & 20.9 & 0.04 & 0.01 & 0.16 \\
\hline Podothecus acipenserinus & 17.6 & 0.01 & 0.01 & 0.04 \\
\hline \multicolumn{5}{|l|}{ Invertebrates } \\
\hline Chrysaora melanaster & 100.0 & 11.27 & 3.16 & 87.86 \\
\hline Cyanea capillata & 44.1 & 0.38 & 0.10 & 2.98 \\
\hline Aequora forskalea & 23.5 & 0.61 & 0.12 & 4.77 \\
\hline Aurelia aurita & 23.5 & 0.55 & 0.10 & 4.27 \\
\hline Berryteuthis magister & 8.8 & 0.02 & 0.03 & 0.11 \\
\hline
\end{tabular}



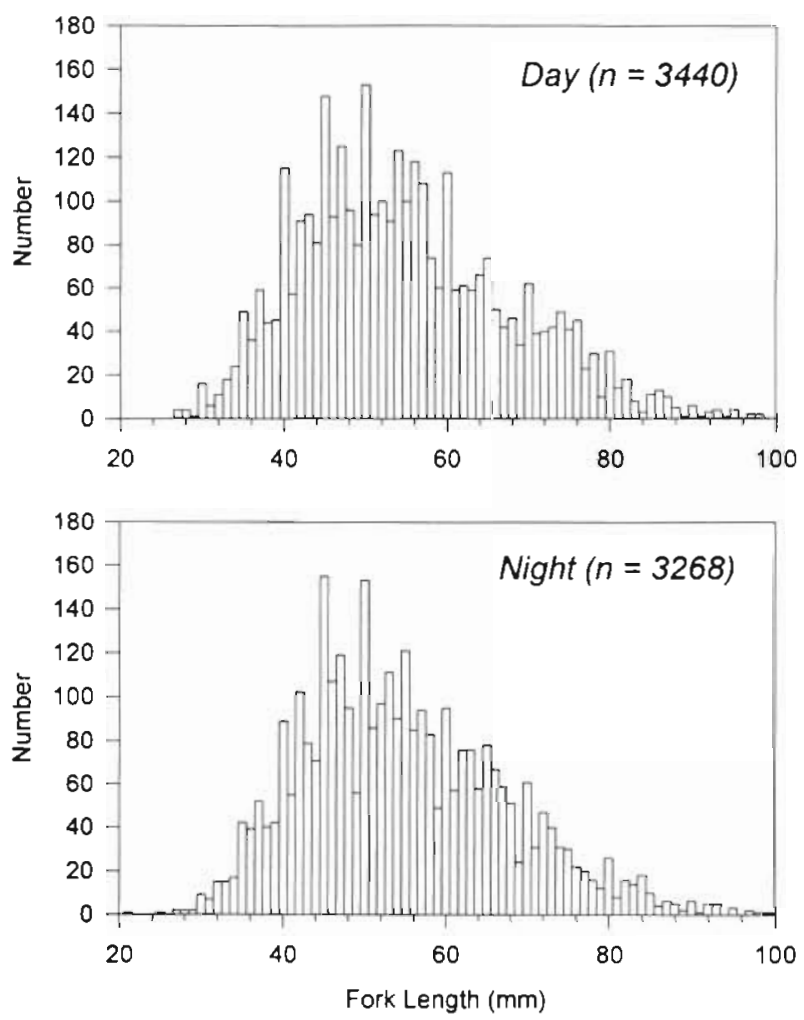

Fig. 8. Theragra chalcogramma. Length distributions of age-0 pollock collected in day and night hauls around the Pribilof Islands

\section{DISCUSSION}

The underwater video observations described here are some of the first made in the pelagic zone of the Eastern Bering Sea Shelf and document a potentially important aspect of walleye pollock life history not adequately described in the literature. Although previously observed from the deck of a vessel (van Hyning $\&$ Cooney 1974) and by scuba divers in surface waters (Hamner 1983), this commensal behavior generally occurred at depths between 10 and $30 \mathrm{~m}$ in the present study, which is beyond sustained scuba diving depths, thus necessitating the use of manned or unmanned submersibles. Moreover, despite the fact that age-0 pollock and large cnidarians dominate the catches of midwater trawl samples (Brodeur et al. 1997) and strongly tend to be associated in community studies based on classification techniques (Brodeur et al. in press) in the Bering Sea, such an association could not be inferred strictly from their coincidence in the same trawls and would therefore require in situ observations.

Owing to the vast numbers of marine bird, mammal and fish predators known to consume juvenile pollock during their first year of life (Livingston 1993, Brodeur
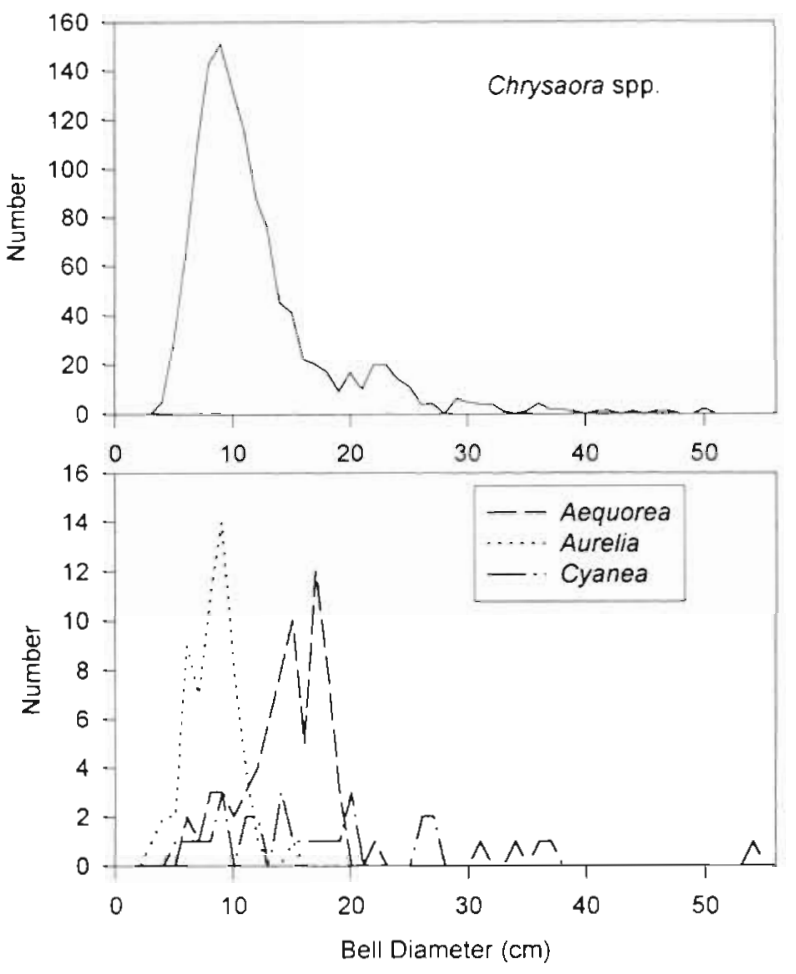

Fig. 9. Umbrella (bell) diameters of the common gelatinous zooplankton collected around the Pribilof Islands

\& Wilson 1996a), pollock can undergo adjustments and perhaps even recruitment failure during the juvenile stage despite having a seemingly adequate supply of larvae and food resources (Brodeur \& Bailey 1996). In other parts of their range, such as in the Gulf of Alaska and off Japan, juvenile pollock are known to recruit to inshore nursery areas in bays and inlets, which may provide not only good feeding conditions but may also afford some protection from avian, mammalian and piscine predators which are concentrated in offshore waters. For pollock spawned over or transported to the central shelf of the eastern Bering Sea, there are relatively few enclosed areas that could serve as nursery grounds in this broad featureless region. The only land mass projecting above sea level is the Pribilof Island Archipelago, which consists of 5 relatively small islands approximately $470 \mathrm{~km}$ from the mainland. The waters surrounding these islands are very productive in terms of prey concentrations due to structural fronts which exist around the $50 \mathrm{~m}$ isobath (Kinder et al. 1983, Coyle \& Cooney 1993, Brodeur et al. 1997). However, these fronts are not likely to be a haven from predation since they are the feeding grounds for a large number of land-based piscivorous birds (mainly murres Uria spp. and kittiwakes Rissa spp.) and marine mammals (mainly northern fur seal Callorhinus ursatus) that are known to feed on age-0 pollock (Coyle et 
al. 1992, Springer 1992, Decker \& Hunt 1996). Since these birds and mammals are primarily visual predators, the time of greatest juvenile pollock vulnerability is likely to be during the day. Because much physical structure in the environment is lacking, it is plausible that juvenile pollock utilize biotic structures such as large medusae as refugia from predation during daytime, thereby increasing their likelihood of survival. Duffy (1988) has shown that butterfish Peprilus triacanthus normally commensal with Cynaea capillata, but which are physically dislodged from their hosts, quickly become prey to opportunistic avian predators.

Another way that juvenile pollock and other fishes might benefit from their association with medusae is if they were to consume parts of the medusae or food particles previously captured by the medusae but not yet transported to the gastric cavity (Mansueti 1963). The diets of a wide size range of age-0 walleye pollock were examined from locations where this commensal relationship with gelatinous zooplankton was observed. Most prey eaten were planktonic (copepods, euphausiids, pteropods, and chaetognaths), although the larger individuals (>70 mm) consumed some epibenthic prey (harpacticoid copepods, cumaceans) taxa (Brodeur et al. 1997). Although some pelagic prey could have been secondarily consumed from the tentacles of the medusae, there was no evidence of direct consumption of gelatinous material that would indicate that age-0 pollock consumed parts of their hosts. Even hyperiid amphipods, which are well-known parasitoids of gelatinous zooplankton (Laval 1980) and were found in abundance in the plankton tows that collected these cnidarians, were not found in the stomachs of juvenile pollock, further indicating that these fish probably feed some distance away from their hosts (see also Dahl 1961, Tolley 1987). There is no evidence presently available to suggest that the association benefits the medusae in any way (e.g. removal of ectoparasitic hyperiid amphipods by pollock); thus, the age-0 pollock are considered to be facultative commensals on these medusae. Alternatively, this relationship may result from a thigmotactic response on the part of the juveniles to any structure in the pelagic realm (Rountree 1989, Kingsford 1993), and this type of association may occur with any floating object, such as drifting kelp and flotsam (Fedoryako 1989, Kingsford 1993).

It is interesting to note that while age-0 pollock $>40 \mathrm{~mm}$ may derive some benefit from associating with gelatinous zooplankton, there is some evidence to suggest that large medusae prey on earlier juvenile stages of pollock in the Bering Sea in the summer (Hamner 1983). In fact, one Chrysaora melanaster collected during this cruise was found to contain 2 partially-digested juvenile pollock $(\approx 30 \mathrm{~mm})$ in its gastric cavity. It is not presently known what predatory impact medusae might have on age-0 pollock, but most of the predation probably occurs on much earlier life stages than were generally present during the September cruise. Most pollock caught at this time are of a size at which they either are able to maintain a safe distance from the nematocysts in the scyphomedusan tentacles or have developed an immunity to the discharge of their host's stinging cells (Dahl 1961).

It is not surprising that prowfish were commonly associated with large medusae. One of the earliest accounts of this species in the Bering Sea documents an association with Cyanea (Scheffer 1940). Prowfish lack strong sustained swimming ability and their fins are adapted to making tight turns as would be required to maneuver around tentacles (cf. Horn 1975). In contrast to juvenile pollock, which left the medusae when approached by the ROV, prowfish darted for safety within the tentacles. Also, no prowfish were observed more than $1 \mathrm{~m}$ away from a jellyfish during any time of the day or night. Thus, it seems likely that this species is an obligate commensal with large medusae until it descends to the bottom as an adult.

The implications of the observed commensal behavior are quite apparent. If juvenile pollock are symbiotic with gelatinous zooplankton until they reach a size at which they can escape most gape-limited predators, then the amount of suitable medusae 'habitat' available to them may be a determinant of recruitment success. There are few quantitative data available on the densities of large gelatinous zooplankton present in the Bering Sea. Coyle \& Cooney (1993) found that pelagic cnidarians comprised the vast majority of the biomass catch of small $\left(1 \mathrm{~m}^{2}\right)$ nets in the vicinity of the Pribilof Islands in 1987 and 1988. These authors suggested that the medusae may actively aggregate or passively be concentrated in convergent fronts which encircle both main islands. Many large medusae, including both Chrysaora melanaster and Cyanea capillata, were observed in high densities along surface convergences caused by Langmuir cells in the Bering Sea (Hamner \& Schneider 1986).

These large carnivorous medusae may affect earlier stages of pollock by either directly consuming them or by competing with them for potentially limited prey resources (Arai 1988). However, as hypothesized here, some positive benefit (i.e. shelter from predation) could be derived by juvenile pollock through association with medusae at a later stage. Based on by-catch of systematic trawl surveys (Brodeur et al. unpubl.), there has been a substantial increase since 1990 in the biomass of large scyphomedusae in the eastern Bering Sea similar to that seen in other ecosystems (Mills 1995). It is of interest to note that no strong year classes of walleye pollock have appeared since 1989 (V. Wespestad, Alaska Fisheries Science Center, pers. comm.), although the 
intervening period is too brief to draw any definite conclusions. Regardless of their effect on population levels of pollock, the meso- and fine-scale features in the distribution of medusae, such as their propensity to be found in high densities in surface convergences set up by Langmuir circulation in the Bering Sea (Hamner \& Schneider 1986), may need to be taken into account in designing studies to determine the horizontal and vertical distribution patterns and assess the abundance of juvenile pollock as well as other pelagic juvenile gadoids (Koeller et al. 1986, Hay et al. 1990).

The ROV observations by depth and the limited acoustic data presented here agree with other field (Bailey 1989, Brodeur \& Wilson 1996b) and laboratory (Sogard \& Olla 1996a) data which suggest that at least some of the juvenile pollock migrate vertically and change their aggregation patterns on a diel basis. Although many of the age- 0 pollock are co-located with gelatinous zooplankton that may have settled near the pycnocline during the day, some fish, presumably the larger individuals (Bailey 1989), migrate through the thermocline (see smaller peak around $55 \mathrm{~m}$ in Fig. 3). It is not known why these fish do not utilize the shelter afforded by the medusae, but perhaps they have found it more beneficial to migrate further down in the water column for trophic or energetic reasons (see Bailey 1989, Sogard \& Olla 1996b). The video observations also document occurrences of pollock aggregations close to the surface during night deployments. Since the acoustic transducer was located at $14 \mathrm{~m}$, it was not possible to acoustically detect the presence of near-surface aggregations of fish; however, the integrated water-column backscattering from the transducer depth to the bottom was generally greater during daytime than nighttime for the same location, which would indicate that a proportion of the total fish biomass is at depths shallower than the transducer at night (see also Brodeur \& Wilson 1996b). Although no visual records of near-surface medusae similar to that done by Hamner \& Schneider (1986) were made, few medusae were observed at the surface either by the ROV or from the deck of the vessel during either day or night on this cruise.

There is still much uncertainty concerning the motivation for juvenile pollock to vertically migrate on a diel basis, but there is substantial evidence that most age-0 pollock are found closer to the surface at night than during the day (Bailey 1989, Brodeur \& Wilson 1996b, R. Brodeur unpubl.). Laboratory studies have shown that juvenile pollock alter their vertical distribution based upon a number of extrinsic stimuli, including the presence of a predator or thermocline (Sogard \& Olla 1993). Descending to deep waters during the daytime may make these juveniles less susceptible to surface-feeding visual predators, such as marine mam- mals and seabirds, but migrating all the way to the bottom exposes them to potential cannibalism by older age classes of pollock (Dwyer et al. 1987, Bailey 1989) and to predation by other bottom fishes (Livingston 1993). A viable alternative for age-0 pollock is to migrate only partially down the water column during the day and take refuge within a layer of medusae accumulated near the pycnocline. This migratory and shelter-seeking behavior may be a defense employed by pollock to minimize encounters with potential predators in what is apparently a 'top-down' controlled pelagic ecosystem (Springer 1992, Verity \& Smetacek 1996). More experimental and field work is clearly needed to derive a better understanding of the adaptive significance of this commensal behavior and the temporal and spatial extent of the associations.

Acknowledgements. This study was conducted as part of the Bering Sea Fisheries Oceanography Coordinated Investigations (FOCI) project of NOAA's Coastal Ocean Program. I thank Lance Horn for his skillful piloting of the ROV and the scientists and crew aboard the NOAA ship 'Miller Freeman' for their assistance with all phases of the field work. I am grateful to Morgan Busby and Claudia Mills for their assistance in identifying fish and medusae, respectively, on the videos and in the trawl catches, Matt Wilson for his analysis of trawl catches, Jennifer Staver for reviewing and analyzing many hours of videotapes and for assisting in the analysis of the video data, Kathy Mier for help on statistical analysis, and Sigrid Salo for providing CTD data. I also thank Kevin Bailey, Gary Stauffer, Art Kendall, Jennifer Purcell, Mary Arai, George Hunt, and 2 anonymous reviewers for helpful comments on the manuscript. Funding for the ROV was provided by the National Undersea Research Center in Fairbanks, Alaska. This research was sponsored by the NOAA Coastal Ocean Program through the Bering Sea Fisheries Oceanography Coordinated Investigations and is FOCI Contribution No. B286.

\section{LITERATURE CITED}

Arai MN (1988) Interactions of fish and pelagic coelenterates Can J Zool 66:1913-1927

Arai MN (1997) A functional biology of Scyphozoa. Chapman \& Hall, London

Bailey KM (1989) Interaction between the vertical distribution of juvenile walleye pollock Theragra chalcogramma in the eastern Bering Sea, and cannibalism. Mar Ecol Prog Ser $53: 205-213$

Bailey RS (1975) Observations on the diel behaviour patterns of North Sea gadoids in the pelagic phase. J Mar Biol Assoc UK 55:133-142

Brodeur RD, Bailey KM (1996) Predation on the early life stages of marine fish: a case study on walleye pollock in the Gulf of Alaska. In: Watanabe Y, Yamashita Y, Oozeki $Y$ (eds) Survival strategies in early life stages of marine resources. A.A. Balkema, Rotterdam, p 245-259

Brodeur RD, Busby MS, Wilson MT (1995) Summer distribution of early life stages of walleye pollock, Theragra chalcogramma, and associated species in the western Gulf of Alaska. Fish Bull US 93:603-618

Brodeur RD, Livingston PA, Loughlin TM, Hollowed AB 
(1996) Ecology of juvenile walleye pollock Theragra chalcogramma. NOAA Tech Rep NMFS 126

Brodeur RD, Wilson MT (1996a) A review of the distribution, ecology and population dynamics of age-0 walleye pollock in the Gulf of Alaska. Fish Oceanogr 5(Suppl 1):148-166

Brodeur RD, Wilson MT (1996b) Mesoscale acoustic patterns of juvenile walleye pollock (Theragra chalcogramma) in the western Gulf of Alaska. Can J Fish Aquat Sci 52 $1951-1963$

Brodeur RD, Wilson MT, Napp JM, Stabeno PJ, Salo S (1997) Distribution of juvenile pollock relative to frontal structure near the Pribilof Islands, Bering Sea. In: Proc Int Symp Role of Forage Fishes in Marine Ecosystems. Alaska Sea Grant Publ AK-SG-97-01, p 573-589

Brodeur RD, Wilson MT, Walters GE, Melnikov IV (in press) Forage fishes in the Bering Sea: distribution, species associations, and biomass trends. In: Loughlin TR, Ohtani $\mathrm{K}$ (eds) The Bering Sea: physical, chemical, and biological dynamics. Univ of Alaska Sea Grant Press

Coyle KO, Cooney RT (1993) Water column scattering and hydrography around the Pribilof Islands, Bering Sea. Cont Shelf Res 13:803-827

Coyle KO, Hunt GL Jr, Decker MB, Weingartner TJ (1992) Murre foraging, epibenthic sound scattering, and tidal advection over a shoal near St. George Island, Bering Sea. Mar Ecol Prog Ser 83:1-14

Dahl E (1961) The association between young whiting, Gadus merlangus, and the jelly-fish Cyanea capillata. Sarsia 3: $47-55$

Decker MB, Hunt GL Jr (1996) Foraging by murres (Uria spp.) at tidal fronts surrounding the Pribilof Islands, Alaska, USA. Mar Ecol Prog Ser 139:1-10

Duffy DC (1988) Predator-prey interactions between common terns and butterfish. Ornis Scand 19:160-163

Dwyer DA, Bailey KM, Livingston PA (1987) Feeding habits and daily ration of walleye pollock (Theragra chalcogramma) in the eastern Bering Sea, with special reference to cannibalism. Can J Fish Aquat Sci 44:1972-1984

Fedoryako BI (1989) A comparative characteristic of oceanic fish assemblages associated with floating debris. J Ichthyol 29:128-137

Hamner W (1983) Gelatinous zooplankton of the Bering Sea. In: PROBES: processes and resources of the Bering Sea Shelf, Final Report Vol II. Nat Sci Foundation, Washington, DC, p 211-229

Hamner W, Schneider D (1986) Regularly spaced rows of medusae in the Bering Sea: role of Langmuir circulation. Limnol Oceanogr 31:171-177

Hay SJ, Hislop JRG, Shanks AM (1990) North Sea scyphomedusae: summer distribution, estimated biomass and significance particularly for O-group gadoid fish. Neth J Sea Res 25:113-130

Horn MH (1975) Swim-bladder state and structure in relation to behavior and mode of life in Stromateoid fishes. Fish Bull US 73:95-109

Kinder TH, Hunt GL Jr, Schneider DC, Schumacher JD (1983) Correlation between seabirds and oceanic fronts around the Pribilof Islands, Alaska. Estuar Coast Shelf Sci 16: $309-319$

Editorial responsibility: Jennifer Purcell (Contributing Editor), Cambridge, Maryland, USA
Kingsford MJ (1993) Biotic and abiotic structure in the pelagic environment: importance to small fishes. Bull Mar Sci 53: $393-415$

Koeller PA, Hurley PCF, Perley P, Neilson JD (1986) Juvenile fish surveys on the Scotian Shelf: implications for year-class size assessments. J Cons Int Explor Mer 43: $59-76$

Laval P (1980) Hyperiid amphipods as crustacean parasitoids associated with gelatinous zooplankton. Oceanogr Mar Biol Annu Rev 18:11-56

Livingston PA (1993) Importance of predation by groundfish, marine mammals and birds on walleye pollock Theragra chalcogramma and Pacific herring Clupea pallasi in the eastern Bering Sea. Mar Ecol Prog Ser 102:205-215

Mansueti R (1963) Symbiotic behaviour between small fishes and jellyfishes, with new data on that between the stromateid, Peprilus alepidotus, and the Scyphomedusae, Chrysaora quinquecirrha. Copeia 1963:40-80

Mills CE (1995) Medusae, siphonophores, and ctenophores as planktivorous predators in changing global ecosystems. ICES J Mar Sci 52:575-581

Rountree RA (1989) Association of fishes with fish aggregation devices: effects of structure size on fish abundance. Bull Mar Sci 44:960-972

Scheffer VB (1940) Two recent records of Zaprora silenus Jordan from the Aleutian Islands. Copeia 1940:203

Sogard SM, Olla BL (1993) Effects of light, thermoclines and predator presence on vertical distribution and behavioral interactions of juvenile walleye pollock. Theragra chalcogramma Pallas. J Exp Mar Biol Ecol 167:179-195

Sogard SM, Olla BL (1996a) Diel patterns of behavior in juvenile walleye pollock, Theragra chalcogramma. Environ Biol Fishes 47:379-386

Sogard SM, Olla BL (1996b) Food deprivation affects vertical distribution and activity of a marine fish in a thermal gradient: potential energy-conserving mechanisms. Mar Ecol Prog Ser 133:43-55

Springer AM (1992) A review: walleye pollock in the North Pacific - How much difference do they really make? Fish Oceanogr 1:80-96

Thiel ME (1976) Wirbellose Meerestiere als Parasiten, Kommensalen oder Symbionten in oder an Scyphomedusen. Helgol Meeresunters 28:417-446

Thiel ME (1978) Das Zusammenleben von Jung- und Kleinfischen mit Semaeostomen (Scyphomedusae). Mitt Hambg Zool Mus Inst 75:19-47

Tolley SG (1987) Association of young Chloroscombrus chrysurus (Pisces: Carangidae) with the jellyfish Aurelia aurita. Copeia 1987(1):216-219

van Hyning JM, Cooney RT (1974) Association of walleye pollock. Theragra chalcogramma, with the jellyfish, Cyanea. Copeia 1974:791

Verity PG, Smetacek V (1996) Organism life cycles, predation, and the structure of marine pelagic ecosystems. Mar Ecol Prog Ser 130:277-293

Wilson MT, Brodeur RD, Hinckley S (1996) Distribution and abundance of age-0 walleye pollock. Theragra chalcogramma, in the western Gulf of Alaska during September 1990. NOAA Tech Rep NMFS 126:11-24

Submitted: March 25, 1997; Accepted: December 9, 1997

Proofs received from author(s): February 18, 1998 